\title{
Comparison of Suture Materials in Caesarean Skin Closure.
}

\author{
Dr.Priyanka Verma ${ }^{1}$ Dr.Kulsum Ansari ${ }^{2}$ \\ ${ }^{1,2}$ Obstetrics And Gynaecology Department, Pravara Rural Hospital /Pravara University, INDIA.
}

\begin{abstract}
:
Aim: Comparison of the rate of wound complications, pain, and patient satisfaction based on suture material.

Methods: A total of 250 consecutive women undergoing primarycaesarean section with low transverse incision were prospectively included. The primary outcome was wound complication rate including infection, dehiscence, hematoma, and hypertrophic scar formation within a 6-week period after operation. Secondary outcomes were skin closure time, the need for use of additional analgesic agent, pain score on numeric rating scale, cosmetic score, and patient scar satisfaction scale.

Results: Absorbable vicryl was used in 108 patients and nonabsorbableethilon was used in 142 patients. Wound complication rates were similar based on the type of suture material. Skin closure time is longer in nonabsorbable suture material group. There was no difference between groups in terms of postoperative pain, need for additional analgesic use, late phase pain, and itching at the scar. Although the cosmetic results tended to be better in the absorbable group in primary surgery patients, there was no significant difference in the visual satisfaction of the patients.

Conclusions: Absorbable and non absorbable suture materials were compared in caesarean section operation skin closure and the absorbable suture materials gave a better result as compared to non-absorbable suture material.
\end{abstract}

\section{Introduction}

Caesarean sections are one of the most commonly performed abdominal operations in women worldwide [1]. Wound healing is an important factor for lower complication rate and patient satisfaction in patients undergoing caesarean section. Tully et al. showed that $73.9 \%$ of the obstetricians preferred to close skin with subcuticular sutures using Prolene (41.1\%), Vicryl (17.5\%) followed by dexon (13.5\%), and staples (10.4\%) [2]. Thesubcuticular absorbable sutures and surgical staples in caesarean wound closure were compared in the literature. Although there are conflicting results, closure with subcuticular suture materials were reported to be more advantageous in terms of wound healing, better cosmetic results and more patient satisfaction rates $[3,4]$. The outcome of wound healing and patient satisfaction based on the use of subcuticular suture material (absorbable versus nonabsorbable) is unknown. The aim of this study is to compare the rate of wound complications, pain, and patient satisfaction based on used subcuticular suture material.

\section{Materials And Methods}

A total of 250 consecutive patients with viable pregnancies greater than 28 gestational weeks undergoing scheduled or unscheduled first caesarean delivery with low transverse incision were prospectively included between July 2016 and January 2017 at Pravara Rural Hospital, Loni, Ahmednagar, Maharashtra, India. The randomization of the patients to the groups was made by weekly alternating the type of suture (absorbable or nonabsorbable) used in caesarean operations. Obstetricians performing the operation were blind for the procedure characteristics including type of suture material, time needed for skin closure, and length of the wound. An inquiry form was filled by a resident from the study team the day after the operation and at the 6th weeks of follow-up. Wound infection was defined as any discharge, mild to severe requiring dressing and antibiotic use. Wound dehiscence was defined as separation of skin edges more than $1 \mathrm{~cm}$ in length. Hematoma was defined as wound swelling more than $1 \mathrm{~cm}$ in diameter accompanied by changing in colour of the skin. Hypertrophic scar was defined as pink-red coloured, hard, itchy, visible, and raised from the normal tissue level scar.

\subsection{Exclusion Criteria}

Patients with inability to obtain informed consent (emergent cases in which there was no time to get informed consent and patients who did not prefer to be in such a study protocol), foetal death, history of nonobstetric abdominal operation, known diabetes or gestational diabetes (except from abnormal glucose tolerance test values under control with diet only), any known immunological disorder, history of allergy for antibiotics and analgesics, and steroid drug usage were excluded. Patients implemented a nonroutine procedure (midline skin incision, postpartum hysterectomy or relaparotomy) because of an unexpected complication and patients who did not come for a second visit were also excluded.

DOI: $10.9790 / 0853-1603077780 \quad$ www.iosrjournals.org $\quad 77 \mid$ Page


The total number of the caesarean operations during the study period was 453 in our hospital. The main reasons for exclusion were lack of follow-up in 91 (20\%), inability to obtain informed consent in 52 (11.8\%), and presence of diabetes in $16(3.5 \%)$ patients.

\subsection{Operative Technique}

Skin of the patients was cleaned with povidone iodine 3 to 4 minutes before the operation started. Prophylactic antibiotic (2nd generation cephalosporin) was administered in all patients. The same operation technique (Pfannenstiel technique) was used for all patients. Subcutaneous tissues were closed with interrupted sutures (2.0 Vicryl) in case of more than $1 \mathrm{~cm}$ subcutaneous tissue thickness. 2.0 Vicryl was used as absorbable and 2.0 Ethilon was used as nonabsorbable suture material for skin closure. Closure of the skin was performed by the attending physician who performed the operation and did not have information about the study protocol. Nonabsorbable suture materials were removed at postoperative 7 th day. All patients included in the study were advised not to use any medication that would potentially affect wound healing. Wound evaluations were initially performed at hospital discharge at postoperative day 4 and at 6th week of follow-up. The primary outcomes were complications related to wound healing (infection, dehiscence, hematoma, and hypertrophic scar formation) at 6th week of follow-up. Secondary outcomes were operative time, pain score on numeric rating scale $(\mathrm{NRS})(0=$ no pain; $2=$ mild; $5=$ moderate; $7=$ severe; $10=$ excruciating $)$, itching at the scar site, cosmetic score (no scar or just a line, mild ridge with minimal change in colour, and presence of severe scar $[>0,5 \mathrm{~cm}$ ridge and red in colour] $)$, and patient scar assessment scale $(1=$ minimum and $10=$ maximum $)$. NRS, cosmetic score, and patient scar assessment scale were evaluated by asking the patient verbally to grade the extent and severity of the scar or pain on a scale of zero to ten for NRS and one to ten for patient scar assessment scale [ㅁ-ㅁ].

\section{Results}

A total of 250 patients underwent caesarean section. Absorbable (2.0 Vicryl) was used in 108 (43.2\%) and non absorbable (2.0 Ethilon) was used in 142 (56.8\%) patients. Baseline characteristic including age, type, and length of skin incisions was similar in absorbable and nonabsorbable suture material groups for both primary and repeat caesarean patients (Table 1). Wound complication rates were similar in both the groups based on the type of suture material (Table 2). Skin closure time was longer in nonabsorbable suture material group. There was no statistical difference between absorbable and nonabsorbable suture groups in terms of postoperative pain, need for additional analgesic use, itching, and pain at the scar tissue at 6th weeks follow-up (Table $\underline{3}$ ). Although the cosmetic results tended to be better in nonabsorbable group in primary surgery patients, there were no significant differences in the visual satisfaction of the patients (Table $\underline{3}$ ).

Table 1: Descriptive statistics of study groups

\begin{tabular}{|l|l|l|c|}
\hline \multicolumn{3}{|c|}{ Primary Ceasarean } \\
\hline & $\begin{array}{l}\text { Absorbable } \\
(\mathrm{N}=80)\end{array}$ & $\begin{array}{l}\text { Non-Absorbable } \\
(\mathrm{N}=87)\end{array}$ & P Value \\
\hline Age (Years) (Mean $\pm \mathrm{Sd})$ & $26.78 \pm 4.83$ & $27.11 \pm 5.35$ & $0.678^{* *}$ \\
\hline Bmi (Mean $\pm \mathrm{Sd})$ & $27.24 \pm 4.48$ & $28.38 \pm 4.88$ & $0.130^{* *}$ \\
\hline Wound Length $(\mathrm{Mm})$ & & & \\
\hline Mean $\pm \mathrm{Sd}$ & $11.00 \pm 1.36$ & $11.27 \pm 1.70$ & \\
\hline Median $\left(25^{\text {th }}-75^{\text {th }}\right)$ & $11(10-12)$ & $11(10-12)$ & $0.813^{* *}$ \\
\hline
\end{tabular}

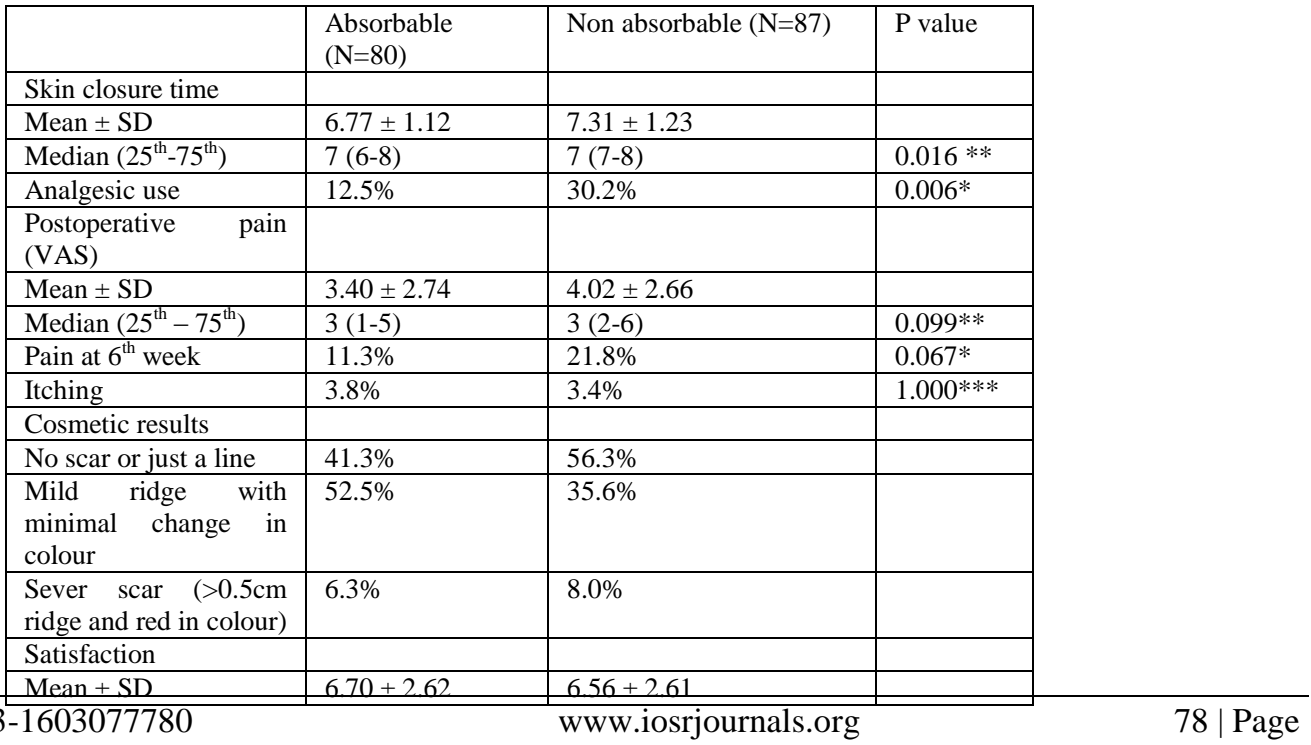




\begin{tabular}{|l|l|l|l|}
\hline Median $\left(25^{\text {th }}-75^{\text {th }}\right)$ & $8(5-9)$ & $7(5-9)$ & $0.717^{* *}$ \\
\hline & & & \\
\hline
\end{tabular}

Table 2: Comparison of the groups in terms of the primary outcomes (complication rates). *Chi square test. ** Fisher's exact test

\begin{tabular}{|l|l|l|l|}
\hline \multirow{2}{*}{ Complication } & & & \\
& Absorbable $(\mathrm{n}=80)$ & Non absorbable $(\mathrm{n}=87)$ & P value \\
\hline Wound infection $(\%)$ & $22.5 \%$ & $14.9 \%$ & $0.210^{*}$ \\
\hline Hematoma & $6.3 \%$ & $3.4 \%$ & $0.480^{* *}$ \\
\hline Dehiscence & 5.0 & 5.7 & $1.000^{* *}$ \\
\hline Hypertrophic scar & $3.8 \%$ & $2.3 \%$ & $0.668^{* *}$ \\
\hline
\end{tabular}

Table 3: Comparison of the groups in terms of the secondary outcomes.

*Chi square, **Mann-Whitney U test, ***Fisher's exact test.

\section{Discussion}

Functional and cosmetic aspects of caesarean surgeries gain increasing importance in recent years. There is still a lack of data in terms of the best method for skin closure in caesarean operations $[9,10]$. There are several studies in the literature comparing staples with suture in closure of caesarean incisions [풀, $\underline{7}, \underline{10}-\underline{13}]$. A meta-analysis which included 877 women from 5 studies compared the use of staples and subcuticular sutures. Study results showed that wound dehiscence and complication rates increased with staples, although the operation time was shortened only by a mean of 5.05 minutes. The authors recommended that subcuticular closure of the skin should be preferred [12]. Similar results were found by Mackeen et al. in 2015 [13]. Frishman et al. compared the staples with absorbable subcuticular suture in 66 women undergoing caesarean section and reported that operation time was significantly shorter with the use of staples. But the use of absorbable subcuticular suture resulted in less pain and use of lower dose of analgesics [11, 14]. A 2012 Cochrane review reported that staples and subcuticular absorbable sutures were similar in terms of wound infection and wound complication rates except that the incidence of wound dehiscence was increased with early (<4 days) removal of staples in women with Pfannenstiel incisions [9].

According to a recent prospective, randomized study closing caesarean incisions with suture is associated with $57 \%$ decrease in wound complications compared to closure with staples [13] along with better patient satisfaction rates [15]. Gaertner et al. compared subcuticular sutures with staples in both subcuticular layer closure and nonclosure group of patients and found no significant difference among the groups in terms of wound complications and patient satisfaction at 4th month of follow-up [16].

Based on the results of the abovementioned studies, subcuticular sutures seem to be more advantageous compared to mattress sutures $[\underline{3}, \underline{12}, \underline{13}]$. Tan et al. conducted a study comparing the suture materials and reported that absorbable and nonabsorbable sutures have similar short-term outcomes but nonabsorbable sutures have a disadvantage of requirement of removal. Additionally, late-term itching at the scar site was seen more frequently in absorbable suture material group possibly due to the late absorption of this kind of suture material [17]. This study was a randomized, controlled study comparing absorbable and nonabsorbablesuture materials in low-transverse incisions. Inclusion of obstetric and nonobstetric cases as well as diabetic cases was the downside of this study. In our study, we compared the most commonly used suture materials (Vicryl and Ethilon) [2] just in caesarean sections and performed a stratified analysis for first time. In addition, we excluded patients with diabetes which is an important confounder in wound healing.

\subsection{Study Limitations}

The major limitation of this study was the difference in the number of the patient population in the study groups despite the fact that we expected them to be similar when making the sample size calculations. However this was due to the weekly randomization process and was not expected to have confounder effect on the results of our study because patient characteristics such as age, BMI, and wound length were found similar.

\section{Conclusion}

Our results showed that is a tendency to get better wound healing and appearance in the wound with absorbable suture materials. There was no significant difference in terms of wound complications, although this difference did not affect the patient's satisfaction rate. 


\section{References}

[1]. L. Gibbons, J. M. Belizán, J. A. Lauer, A. P. Betrán, M. Merialdi, and F. Althabe, "The global numbers and costs of additionally needed and unnecessary caesarean sections performed per year: overuse as a barrier to universal coverage," World Health Report, World Health Organization, Geneva, Switzerland, 2010.View at Google Scholar

[2]. L. Tully, S. Gates, P. Brocklehurst, K. McKenzie-McHarg, and S. Ayers, "Surgical techniques used during caesarean section operations: results of a national survey of practice in the UK," European Journal of Obstetrics Gynecology and Reproductive Biology, vol. 102, no. 2, pp. 120-126, 2002. View at Publisher · View at Google Scholar · View at Scopus

[3]. D. Figueroa, V. C. Jauk, J. M. Szychowski, R. Garner, J. R. Biggio, and W. W. Andrews, "Surgical staples compared with subcuticular suture for skin closure after cesarean delivery: a randomized controlled trial," Obstetrics \&Gynecology, vol. 121, no. 5, pp. 33-38, 2013. View at Publisher · View at Google Scholar · View at Scopus

[4]. A. D. MacKeen, T. Devaraj, and J. K. Baxter, "Cesarean skin closure preferences: a survey of obstetricians," Journal of MaternalFetal and Neonatal Medicine, vol. 26, no. 8, pp. 753-756, 2013. View at Publisher · View at Google Scholar · View at Scopus

[5]. G. A. Hawker, S. Mian, T. Kendzerska, and M. French, "Measures of adult pain: Visual Analog Scale for Pain (VAS Pain), Numeric Rating Scale for Pain (NRS Pain), McGill Pain Questionnaire (MPQ), Short-Form McGill Pain Questionnaire (SF-MPQ), Chronic Pain Grade Scale (CPGS), Short Form-36 Bodily Pain Scale (SF-36 BPS), and Measure of Intermittent and Constant Osteoarthritis Pain (ICOAP)," Arthritis Care and Research, vol. 63, no. 11, pp. S240-S252, 2011. View at Publisher · View at Google Scholar · View at Scopus

[6]. C. S. Rodriguez, "Pain measurement in the elderly: a review," Pain Management Nursing, vol. 2, no. 2, pp. 38-46, 2001. View at Publisher - View at Google Scholar . View at Scopus

[7]. C. Sharma, A. Verma, A. Soni, M. Thusoo, V. K. Mahajan, and S. Verma, "A randomized controlled trial comparing cosmetic outcome after skin closure with 'staples' or 'subcuticular sutures' in emergency cesarean section," Archives of Gynecology and Obstetrics, vol. 290, no. 4, pp. 655-659, 2014. View at Publisher · View at Google Scholar · View at Scopus

[8]. A. M. Coll, J. R. M. Ameen, and D. Mead, "Postoperative pain assessment tools in day surgery: literature review," Journal of Advanced Nursing, vol. 46, no. 2, pp. 124-133, 2004. View at Publisher · View at Google Scholar · View at Scopus

[9]. A. D. Mackeen, V. Berghella, and M.-L. Larsen, "Techniques and materials for skin closure in caesarean section," Cochrane Database of Systematic Reviews, vol. 14, no. 11, Article ID CD003577, 2012. View at Google Scholar · View at Scopus

[10]. V. Berghella, J. K. Baxter, and S. P. Chauhan, "Evidence-based surgery for cesarean delivery," American Journal of Obstetrics and Gynecology, vol. 193, no. 5, pp. 1607-1617, 2005. View at Publisher • View at Google Scholar · View at Scopus

[11]. F. Alderdice, D. McKenna, and J. Dornan, "Techniques and materials for skin closure in caesarean section," Cochrane Database of Systematic Reviews, vol. 2, Article ID CD003577, 2003. View at Google Scholar · View at Scopus

[12]. F. S. H. Clay, C. A. Walsh, and S. R. Walsh, "Staples vssubcuticular sutures for skin closure at cesarean delivery: a metaanalysis of randomized controlled trials," American Journal of Obstetrics and Gynecology, vol. 204, no. 5, pp. 378-383, 2011. View at Publisher · View at Google Scholar · View at Scopus

[13]. A. D. Mackeen, M. Schuster, and V. Berghella, "Suture versus staples for skin closure after cesarean: a metaanalysis," American Journal of Obstetrics and Gynecology, vol. 212, no. 5, pp. 621.e1-621.e10, 2015.View at Publisher · View at Google Scholar - View at Scopus

[14]. G. N. Frishman, T. Schwartz, and J. W. Hogan, "Closure of Pfannenstiel skin incisions. Staples vs. subcuticular suture," Journal of Reproductive Medicine for the Obstetrician and Gynecologist, vol. 42, no. 10, pp. 627-630, 1997. View at Google Scholar · View at Scopus

[15]. A. D. Mackeen, J. Fleisher, A. Khalifeh, C. M. Pettker, and V. Berghella, "Patient satisfaction and cosmetic outcome in a randomized study of cesarean skin closure," Obstetrics \&Gynecology, vol. 123, pp. 4S-5S, 2014. View at Publisher · View at Google Scholar

[16]. I. Gaertner, T. Burkhardt, and E. Beinder, "Scar appearance of different skin and subcutaneous tissue closure techniques in caesarean section: a randomized study," European Journal of Obstetrics Gynecology and Reproductive Biology, vol. 138, no. 1, pp. 29-33, 2008. View at Publisher · View at Google Scholar · View at Scopus

[17]. P. C. Tan, S. Mubarak, and S. Z. Omar, "Absorbable versus nonabsorbable sutures for subcuticular skin closure of a transverse suprapubic incision," International Journal of Gynecology and Obstetrics, vol. 103, no. 2, pp. 179-181, 2008. View at Publisher · View at Google Scholar · View at Scopus 